\title{
THE NEWER PENICILLINS IN THE TREATMENT OF GONORRHOEA
}

\author{
R. R. WILlCox \\ Consultant in Venereology, St. Mary's Hospital, London, W.2; \\ Member WHO Expert Committee on Venereal Diseases and Treponematoses.
}

Penicillin was introduced for the treatment of gonorrhoea in 1943 at a time when the effectiveness of the sulphonamides had been blunted by the rapid emergence of sulphonamideresistant gonococci. In spite of numerous other effective antibiotics which have since become available, of allergic reactions to penicillin which may sometimes be serious, and of the more widespread occurrence of strains of gonococci less sensitive to penicillin than formerly, penicillin remains-for those not considered likely to be allergic to it - the drug of choice in the treatment of this disease on the grounds of effectiveness, safety, cost and administrative convenience in so far that only 1 or 2 injections are usually sufficient.

The early work concerned with the improvement of penicillin was directed at the purification of the existing sodium and potassium salts and the devising of vehicles (e.g. oilbeeswax and oil-aluminium monostearate) to increase its repository powers. A significant advance was the discovery of procaine penicillin by Buckwalter and Dickinson in 1948 and in recent years, in the treatment of gonorrhoea, there has been a switch from repository preparations to this product which provides sufficiently high blood levels of penicillin to overcome the increasing numbers of less sensitive strains of gonococci. The so-far ultimate of repository penicillins was the discovery of benzathine penicillin a few years later.

The next significant advance was that of Sheehan and Henery-Logan (1957), in the U.S.A. who were the first to convert penicillin $G$ into 6-amino-penicillanic acid and synthesized phenoxymethyl penicillin or penicillin V. Later the English workers Batchelor, Doyle, Nayler and Rolinson (1959) found an economic source of 6-amino-penicillanic acid in fermentation broths and the synthesis of a vast number of new penicillin compounds then became possible. A number of these, e.g., phenethicillin, cloxacillin, ampicillin, are now commercially available.

Most of the new penicillins have to be given by mouth and there are a number of objections

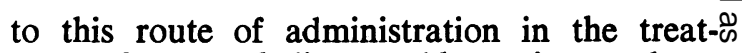
ment of venereal disease. Absorption tends to $\vec{\circ}$ be more variable than by injection methodsand patients with venereal diseases arew notoriously unreliable in taking their medicines in the doses and at the times prescribed. More- $\frac{0}{3}$ over there is a danger that the patient willstop taking his pills when symptoms disappear. and may retain some of the medicine for self- $\infty$ treatment at a later date. Furthermore a 'black응 market' may be fostered. Many of these difficulties are removed if the orally administered drug can be given in one dose under supervisiono in the clinic, or at the most in two doses, andfor this reason such methods have received more intensive investigation than those employing repeated doses over longer periods of tinte.

\section{Difficulties in Comparative Trials}

Comparisons of therapeutic agents in the treatment of gonorrhoea are difficult owing a number of factors. The pattern of sensitivi-o ties of gonococci to penicillin and the proportion of less sensitive strains have been shewn to be patchy geographically and the findings in one $\frac{\alpha}{\circ}$ city are not necessarily comparable with those of another. Similarly such sensitivity patternsō have been shewn to be related to treatment ${ }^{3}$ practices locally in force and therefore also vary with time (Letchner and Nicol, 1961; Willcox, 1962; Morton, 1963).

An even greater difficulty is the distinguishing:of relapse from reinfection in the case of 3 . recurrence. With today's increasing prevalence of gonorrhoea the chances of some recurrences being reinfections must also be higher. Noo satisfactory criteria exist and the presence or absence of a history of further sexual exposure, which is the one usually used, has great limitations. The opportunity is seldom offered o to shew that the new contact is infected and 0 even if this is proved to be the case relapse in N the patient still cannot definitely be excluded.0 So far unpublished work at the London

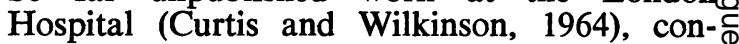
cerning the pattern of sensitivities of gonococci $\stackrel{?}{+}$ to penicillin in untreated cases and in recur- 0 
rences, has shewn a marked trend towards a higher proportion of less sensitive strains in recurrences noted in the first week while in those encountered after this time the pattern is similar to that of untreated cases. These workers suggest, in making an assessment on a group rather than an individual basis, that a fair degree of accuracy will be obtained if, irrespective of history, all recurrences occurring in the first week are classified as relapses and those noted after this time as reinfections. Both methods are used in this paper.

Furthermore it is important that (as in the data presented) assessments are made solely on male patients who are usually likely to be aware of relapse when it occurs and seek advice rather than on females who may not be conscious of relapse until after they have reinfected their partner or infected another male.

In addition to reviewing the literature personal data concerning the treatment of 279 male patients with uncomplicated gonorrhoea with aqueous procaine penicillin by injection, 74 others with benzathine penicillin, 85 with phenoxymethyl penicillin, 148 with phenethicillin, 25 with cloxacillin-all orally, and 356 with ampicillin by mouth and by injection -a total of 967 cases-are presented.

\section{Results}

\section{Aqueous Procaine Penicillin by Injection}

Recently reported failure rates with single injections of 600,000 units of aqueous procaine penicillin have varied from $8.6-11 \%$ in Norway (Gjessing, 1959) to $15.3-20 \%$ in the U.S.A. (Mead, Moor and Bean, 1960) and in Korea (Epstein, 1959) even when this amount has been given daily for 4-5 days.
The data presented refers to the personal results obtained in male patients in London with single doses of 1.2 mega units during 1963 (Table I).

Thus of 279 treated 207 were followed and, based on a history of re-exposure, there were 23 suspected relapses (11.1 per cent of those followed). If only the 12 recurrences in the first week are considered the failure rate would be 4.3-5.8\% depending whether the recurrences were calculated according to the patients followed or the patients treated.

These data will be used as a yardstick of comparison of the results obtained with other preparations.

\section{Benzathine Penicillin By Injection}

Benzathine penicillin by injection has been widely used in the USA for the treatment of gonorrhoea and still is in the treatment of syphilis. At first in gonorrhoea excellent results were obtained with only 300,000 units (O'Brien and Smith, 1952). The long repository powers have been considered useful in ensuring the abortion of simultaneously acquired syphilis and also in preventing reinfection should the patient return to the same sexual environment before the contacts have been treated. For these reasons it is still used but as the serum levels? obtained are insufficient for some of the less sensitive strains of gonococci in circulation (Schamberg, Kalodner and Lentz, 1958) many physicians feel that this product should not be given in the treatment of gonorrhoea for risk of facilitating the selection of such organisms. With single injections of 600,000

TABLE I

1.2 Mega Units of Aqueous Procaine Penicillin by Single Injection

\begin{tabular}{ccccccc}
\hline $\begin{array}{c}\text { Treated } \\
279\end{array}$ & $\begin{array}{c}\text { Followed } \\
207\end{array}$ & $\begin{array}{c}\text { Suspected } \\
\text { failure } \\
23\end{array}$ & $\begin{array}{c}\text { Recurrence in } \\
\text { first week }\end{array}$ & $\begin{array}{c}\% \text { failure } \\
\text { of followed } \\
11.1\end{array}$ & $\begin{array}{c}\% \\
\text { of }\end{array}$ & $\begin{array}{c}\text { recurrence in first week } \\
\text { followed } \\
\text { of }\end{array}$ \\
\hline
\end{tabular}

TABLE II

Benzathine Penicillin by Mouth in Single Doses

\begin{tabular}{lcccccc}
\hline $\begin{array}{c}\text { Dose } \\
\text { mega single }\end{array}$ & Treated & Followed & NGU & Reinfection & Fail & $\begin{array}{c}\% \text { Fail of } \\
\text { followed }\end{array}$ \\
1.2 mega single & 1 & 2 & 1 & - & - & 100.0 \\
$1.5-2.4$ single & 9 & 8 & -1 & -1 & 3 & 100.0 \\
$3.0-4.8$ single & 34 & 33 & 2 & 6 & 10 & 37.5 \\
Total single dose & 46 & 44 & 3 & 7 & 16 & 36.4 \\
\hline
\end{tabular}

*NGU-non gonococcal urethritis. 
units failure rates of $14.6 \%$ are currently being reported in the U.S.A. (Sokoloff and Goldstein, 1963). However, in a personal series of 264 patients treated in London in 1957 with single injections of $0.3-1.2$ mega units an even worse failure rate of $27.4 \%$ was obtained (Willcox, 1958).

\section{Benzathine Penicillin by Mouth}

Even poorer results have been obtained with benzathine penicillin by mouth (Table III).

It is evident that single doses of up to 4.8 mega units were not effective. When two large doses were given each of 2.4 mega units 4-6 hours apart, better results were achieved (Table III).

\section{Phenoxymethyl Penicillin (Penicillin V)}

Used in single oral doses of 1-1.2 mega units (0.625-0.675 g.) phenoxymethyl penicillin is not strikingly successful. Schultz, Shaffer and Stone (1956) had $15.4 \%$ of failures and Love and Weir (1956) could cure only half of their patients. Schultz and colleagues were however to achieve $90 \%$ success with single doses of two mega units $(1.25 \mathrm{~g}$.) or with two doses of 500,000 units $(0.3 \mathrm{~g}$.) at an interval of six hours but this is not general experience and indifferent results were per- sonally obtained with 2-3 mega units (1.25-1.875 g.) given in two doses (Table IV). Generally satisfactory results, exceeding $90 \%$ of success, have been reported with doses of $600,000-1.4$ million units 0.37-0.875 g.) in 517 four-hourly doses (Love? and Weir, 1956; Rajam, Rangiah, Sowmini and Rama, 1958) or with greater amounts up $\overline{\frac{\omega}{0}}$ to 3.6 mega units $\left(2.25 \mathrm{~g}\right.$.) given over $1 \frac{1}{2}-2$ days $\varrho$ (Sheil, 1956; Thurman, 1959) but excellent results can likewise be obtained with multiple $\vec{A}$ doses of potassium benzyl penicillin by mouth. (Eastman, Cook and Bunn, 1956; Schultz and $\vec{\omega}$ Shaffer, 1958; Allison, 1962). Penicillin V has, however, been unable to provide results theo equal of those obtained with single doses of $\stackrel{3}{-}$ aqueous procaine penicillin by injection.

\section{Phenethicillin}

Phenethicillin likewise has not significantly improved on phenoxymethyl penicillin in the treatment of gonorrhoea. Although Marmello and Prigot (1961) had only two failures in? 66 patients given a total of 3-4 g. in divided 0 doses over two days, even with double dosage Allison (1962) had $33.8 \%$ of failures with twe doses each of $0.37 \mathrm{~g}$., Jefferiss and Rosedafe (1961) had $18 \%$ of failures in those followegl given two doses of $0.5 \mathrm{~g}$. and Hilton (196

TABLE III

Benzathine Penicillin Orally in Single and Double Dosage

\begin{tabular}{|c|c|c|c|c|c|c|c|}
\hline $\begin{array}{l}\text { Schedule } \\
\text { Schlo }\end{array}$ & Treated & Followed & $\begin{array}{l}\text { Suspected } \\
\text { fail }\end{array}$ & $\begin{array}{l}\text { Recurrence in } \\
\text { first week }\end{array}$ & $\begin{array}{l}\% \text { fail of } \\
\text { followed }\end{array}$ & $\begin{array}{l}\% \text { recurrence in } \\
\text { of followed }\end{array}$ & $\begin{array}{l}\text { first week } \\
\text { of treated }\end{array}$ \\
\hline $\begin{array}{l}0.6-4.8 \text { mega } \\
\text { Double dose }\end{array}$ & 46 & 44 & 16 & 15 & 36.4 & 34.1 & 32.6 \\
\hline $2.4+2.4$ mega & 28 & 23 & 4 & 2 & 17.4 & 8.7 & 7.1 \\
\hline $\begin{array}{l}\text { Procaine penicillin } \\
1.2 \text { mega }(0.7 \mathrm{~g} .) \\
\text { single injection }\end{array}$ & 279 & 207 & 23 & 12 & 11.1 & 5.8 & 4.3 \\
\hline
\end{tabular}

TABLE IV

Phenoxymethyl Penicillin (V) by Mouth

\begin{tabular}{|c|c|c|c|c|c|c|c|}
\hline \multirow{4}{*}{$\begin{array}{l}\text { Schedule } \\
\text { Single dose } \\
1.25-1.875 \mathrm{~g} . \\
(2-3 \mathrm{mega}) \\
\text { Double dose } \\
1.25-1.875 \mathrm{~g} . \\
(2-3 \text { mega }) \\
\text { Procaine penicillin } \\
1.2 \text { mega }(0.7 \mathrm{~g} .) \\
\text { single injection }\end{array}$} & Treat & Followed & $\begin{array}{l}\text { Suspected } \\
\text { fail }\end{array}$ & $\begin{array}{l}\text { Recurrence in } \\
\text { first week }\end{array}$ & $\begin{array}{l}\% \text { fail of } \\
\text { followed }\end{array}$ & $\begin{array}{l}\% \text { recurrence } \\
\text { of followed }\end{array}$ & $\begin{array}{l}\text { in first week } \\
\text { of treated }\end{array}$ \\
\hline & 43 & 37 & 5 & 5 & 13.5 & 13.5 & 11.6 \\
\hline & 42 & 39 & 9 & 7 & 23.1 & 17.9 & 16.7 \\
\hline & 279 & 207 & 23 & 12 & 11.1 & 5.8 & 4.3 \\
\hline
\end{tabular}


TABLE V

Phenethicillin by Mouth

\begin{tabular}{|c|c|c|c|c|c|c|c|}
\hline 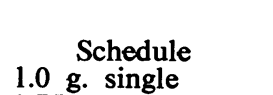 & $\begin{array}{l}\text { Treated } \\
25\end{array}$ & Followed & $\begin{array}{l}\text { Suspected } \\
\text { fail } \\
6\end{array}$ & $\begin{array}{l}\text { Recurrence in } \\
\text { first week } \\
5\end{array}$ & $\begin{array}{l}\% \text { fail of } \\
\text { followed } \\
27.3\end{array}$ & $\begin{array}{l}\text { \% recurrenc } \\
\text { of followed } \\
22.7\end{array}$ & $\begin{array}{l}\text { in first week } \\
\text { of treated } \\
20.0\end{array}$ \\
\hline $\begin{array}{l}\text { double } \\
0.75 \mathrm{~g} \text {. } \\
\text { doub }\end{array}$ & 57 & 47 & 6 & 6 & 12.8 & 12.8 & 10.5 \\
\hline double & 66 & 49 & 8 & 5 & 17.4 & 10.2 & 7.6 \\
\hline $\begin{array}{l}\text { Procaine penicillin } \\
1.2 \text { mega }(0.7 \mathrm{~g} .) \\
\text { single injection }\end{array}$ & 279 & 207 & 23 & 12 & 11.1 & 5.8 & 4.3 \\
\hline
\end{tabular}

using $2.0 \mathrm{~g}$. in divided doses had $46.9 \%$ of failures. The latter worker reported even worse results in patients given single doses of $2.0 \mathrm{~g}$.

Results personally obtained with phenethicillin (see Willcox, 1962) are shewn in Table V.

\section{Cloxacillin ("Orbenin")}

This newer compound is one of the less active in gonorrhoea and when used in single doses of 0.5-1.5 g. less than half of those followed were cured (Table VI).

\section{Ampicillin ("Penbritin")}

Ampicillin, on the other hand seems to be the most active of the newer penicillins in gonorrhoea and the clinical results confirm the laboratory observations of Odegaard (1962) who found that although ampicillin was weaker than benzyl penicillin $G$ against most strains of gonococci it was stronger than phenethicillin or phenoxymethyl penicillin and had a better effect than benzyl penicillin on less sensitive strains.

\section{Ampicillin by Mouth}

Ampicillin has been used by mouth in the treatment of 250 male cases of gonorrhoea, of whom 200 were given single doses of $0.5-1.0 \mathrm{~g}$. and 50 received two split doses each of $1.0 \mathrm{~g}$. (Table VII).

The results obtained with single oral doses of $0.5-1.0 \mathrm{~g}$. of ampicillin were not as good as those achieved with 1.2 mega units of aqueous procaine penicillin by single injection if all methods of assessment are considered. No improvement of results was obtained by increasing the single dose from 0.5 to $1.0 \mathrm{~g}$. The results obtained with $1.0 \mathrm{~g}$. were not as good as those reported by Alergant (1963) who

TABLE VI

Cloxacillin by Mouth

\begin{tabular}{|c|c|c|c|c|c|c|c|}
\hline \begin{tabular}{l}
\multicolumn{1}{c}{ Schedule } \\
0.5 g. single \\
$1.0-1.5$ g. single \\
Total
\end{tabular} & $\begin{array}{c}\text { Treated } \\
5 \\
20 \\
25\end{array}$ & $\begin{array}{c}\text { Followed } \\
5 \\
16 \\
21\end{array}$ & $\begin{array}{c}\text { Suspected } \\
\text { fail } \\
5 \\
6 \\
11\end{array}$ & $\begin{array}{c}\text { Recurrence in } \\
\text { first week } \\
\text { NR } \\
\text { NR } \\
9\end{array}$ & $\begin{array}{c}\% \text { fail of } \\
\text { followed } \\
100.0 \\
37.5 \\
52.4\end{array}$ & $\begin{array}{c}\% \text { recurrenc } \\
\text { of followed } \\
\text { NR } \\
\text { NR } \\
42.9\end{array}$ & $\begin{array}{c}\text { in first week } \\
\text { of treated } \\
\text { NR } \\
\text { NR } \\
36.0\end{array}$ \\
\hline $\begin{array}{l}\text { Procain penicillin } \\
1.2 \mathrm{mega}(0.7 \mathrm{~g} .) \\
\text { single injection }\end{array}$ & 279 & 207 & 23 & 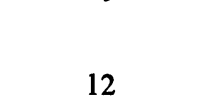 & 11.1 & 5.8 & 4.3 \\
\hline
\end{tabular}

TABLE VII

Ampicillin ("Penbritin") by Mouth

\begin{tabular}{|c|c|c|c|c|c|c|c|}
\hline $\begin{array}{l}\text { Schedule } \\
0.5 \mathrm{~g} \text {. single } \\
0.75 \mathrm{~g} \text {. single } \\
1.0 \mathrm{~g} \text {. single }\end{array}$ & $\begin{array}{c}\text { Treated } \\
100 \\
50 \\
50\end{array}$ & $\begin{array}{c}\text { Followed } \\
84 \\
44 \\
46\end{array}$ & $\begin{array}{c}\text { Suspected } \\
\text { fail } \\
12 \\
7 \\
7\end{array}$ & $\begin{array}{c}\text { Recurrence in } \\
\text { first week } \\
7 \\
4 \\
7\end{array}$ & $\begin{array}{c}\% \text { fail of } \\
\text { followed } \\
14.3 \\
15.9 \\
15.2\end{array}$ & $\begin{array}{c}\% \text { recurrence } \\
\text { of followed } \\
8.3 \\
9.1 \\
15.2\end{array}$ & $\begin{array}{c}\text { in first week } \\
\text { of treated } \\
7.0 \\
8.0 \\
14.0\end{array}$ \\
\hline Total single & 200 & 174 & 26 & 18 & 14.9 & 10.3 & 9.0 \\
\hline $1.0 \mathrm{~g} .+1.0 \mathrm{~g}$ & 50 & 43 & 5 & 1 & 11.6 & 2.3 & 2.0 \\
\hline $\begin{array}{l}\text { Procaine penicillin } \\
1.2 \text { mega }(0.7 \mathrm{~g} .) \\
\text { single injection }\end{array}$ & 279 & 207 & 23 & 12 & 11.1 & 5.8 & 4.3 \\
\hline
\end{tabular}


TABLE VIII

Ampicillin by Injection

\begin{tabular}{|c|c|c|c|c|c|c|c|}
\hline \multirow{3}{*}{$\begin{array}{l}\text { Schedule } \\
250 \mathrm{mg} \text {. single } \\
\text { injection } \\
500 \mathrm{mg} \text {. single } \\
\text { injection }\end{array}$} & Treated & Followed & $\begin{array}{l}\text { Suspected } \\
\text { fail }\end{array}$ & $\begin{array}{l}\text { Recurrence in } \\
\text { first week }\end{array}$ & $\begin{array}{l}\% \text { fail of } \\
\text { followed }\end{array}$ & $\begin{array}{l}\% \text { recurrence in } \\
\text { of followed }\end{array}$ & $\begin{array}{l}\text { first week } \\
\text { of treated }\end{array}$ \\
\hline & 50 & 39 & 12 & 9 & 30.8 & 23.1 & 18.0 \\
\hline & 56 & 44 & 11 & 10 & 25.0 & 22.7 & 17.9 \\
\hline
\end{tabular}

TABLE IX

Ampicillin by Injection and by Mouth Compared

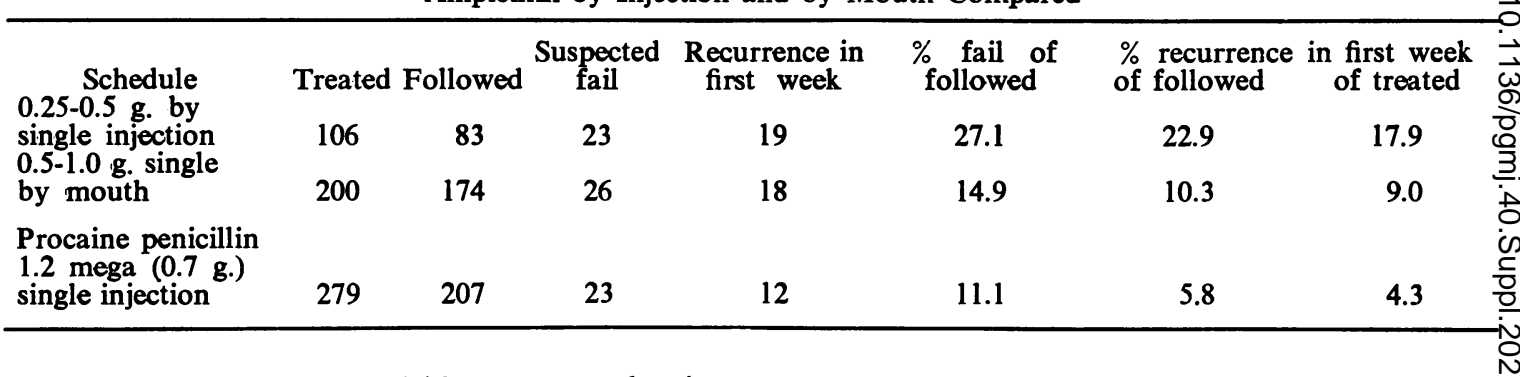

had only ten failures within two weeks in 200 patients $(5 \%)$ but his patients who did not attend for follow-up were presumed to have been cured.

Improved results, quite as good as with aqueous procaine penicillin, were achieved with two split doses each of $1.0 \mathrm{~g}$. of ampicillin orally and there is no doubt that the disease can be adequately cured with multiple dosage.

\section{Ampicillin by Injection}

Eighty-one patients have been treated with single injections of $250-500 \mathrm{mg}$. of ampicillin. No improvement in the failure rate was noted by increasing the dose from $250 \mathrm{mg}$. to $500 \mathrm{mg}$. and the injectable preparation proved inadequate in these single doses. (Table VIII).

The results obtained with ampicillin by injection and by mouth are compared with those with single injection of aqueous procaine penicillin in Table IX. Given by injection $250-500 \mathrm{mg}$. of ampicillin was only half as satisfactory as when 0.5-1.0 g. was given by mouth and single doses by mouth were not quite as efficient as single doses of $1.2 \mathrm{mega}$ units of aqueous procaine penicillin by injection,

\section{Other Penicillins}

Another diamine penicillin, octylethylene diamine penicillin (octacillin), was tried by Gokhale, Charpure and Poonwala (1961) who had no failures in 11 treated with single doses of $375 \mathrm{mg}$. Synnematin B (a penicillin-like compound obtained from (cephalosporium salinosynnematum) was used successfully byg Schwimmer, Henderson and Olson (1961) on 132 cases in single injections of 300,000 units. There were $13 \%$ of recurrences but only尺 $4 \%$ were adjudged to be treatment failures.

\section{Summary and Conclusions}

1. In spite of the existence of numerows other effective antibiotics able to cure gon\&rhoea, of the possibility of allergic reactions and the emergence of strains of gonococci lesss sensitive to penicillin, this antibiotic remainso the agent of choice in the treatment of thiso disease.

2. There are today many forms in which penicillin may be given. Difficulties in assessing comparative data consequent upon varying? sensitivity patterns of strains of gonococci to penicillin and of difficulties in distinguishingo relapse from reinfection are outlined.

3. The disadvantages of oral therapy compared with treatment by injection are stressed. Most of the adverse factors can be obviatedô if oral treatment is given in a single, or at the most-two, doses.

4. Some of the literature is reviewed and the results are presented of treating 279 male patients with acute uncomplicated gonorrhoeaN with aqueous procaine penicillin; 74 others with benzathine penicillin, 85 with phenoxymethyl penicillin, 148 with phenethicillin, $\omega$ 25 with cloxacillin-all by mouth; and $356^{\circ}$ patients with ampicillin by mouth and by을 injection-a total of 967 cases.

5. Best results were obtained with single $\stackrel{\stackrel{\infty}{+}}{+}$ injections of 1.2 mega units of aqueous pro- 
caine penicillin. Indifferent results followed the use of benzathine penicillin by injection owing to the lower serum levels of penicillin obtained, and also following benzathine penicillin by mouth and cloxacillin.

6. Although gonorrhoea can be adequately cured by multiple orally administered doses of benzyl penicillin, phenoxymethyl penicillin, phenethicillin and ampicillin the data presented refers to the results obtained with single or double doses. Phenoxymethyl penicillin and phenethicillin by mouth given in this way proved less useful than aqueous procaine penicillin by single injection.

7. The results obtained with ampicillin in single oral doses approached most closely those of aqueous procaine penicillin by single injection and those obtained by double oral doses of ampicillin were, by some methods of assessment, quite as impressive. Single doses of ampicillin given by injection, however, proved unsatisfactory.

\section{REFERENCES}

Alergant, G. D. (1963): Brit. J. vener. Dis., 39, 225. Allison, J. R., (1962): Antibiot. and Chemother. 12, 225.

Batchelor, E. R., Doyle, F. P., Nayler, S. H. C., and Rolinson, G. N. (1959): Nature, 183, 257-258

Buckwalter, F. A. and Dickinson, H. C. (1948): J. Amer. pharm. Ass., 36, 472.

Curtis, F. R., and Wilkinson, A. E. (1964): Paper presented at Medical Society for Study of Venereal Diseases, London.
Eastman, G., Cook, E. and BunN, P. (1956): N. $Y$. St. J. Med., 56, 241.

EPSTEIN, E. (1959): J. Amer. med. Ass., 169, 1055.

GJESSING, H. C. (1959): Brit. J. vener. Dis., 36, 122.

Gokhale, B. B., Charpure, M. B. and Poonwala, H. E. (1961): Hindustani Antibiotics Bull., Pimpri, 4, 80.

Hilton, A. L. (1961): Brit. J. vener. Dis. 37, 158.

LOVE, J. and WeIR, R. (1956): Antibiot. Ann. (1955-6) p. 521 .

Marmell, M. and Prigot, A. (1961): N. Y. St. J. Med., 61, 2609.

Mead, R. K., Moor, N. F. and Bean, L. L. (1960): U.S. armd. Forces med. J., 11, 111 .

MorTON, R. S. (1963): Brit. J. vener. Dis., 39, 105.

O'Brien, J. F. and SMITH, C. A. (1952): Amer. J. Syph., 36, 519.

ODEGAARD, K. (1962): Brit. med. J., i, 645.

Rajam, R. V., Rangiah, P. N., Sowmini, C. N. and RAMA IYENGER, M. C. (1958): Antiseptic, 55, 125.

SChamberg, I. L., KalodNer, A. and LenTZ., J. W. (1958): Brit. J. vener. Dis., 24, 24.

SchulTz, J. H. and Shaffer, L. W. (1958): Amer. Pract., 9, 922.

SChulTz, J. H., Shaffer, L. W. and Stone, J. (1956): Paper presented at the First International Symposium on Venereal Diseases and Treponematoses, Washington, D.C.

SCHWIMMER, B., HENDERSON, N. D. and Olson, B. H. (1961): Pub. Hlth. Rep. (Wash.), 76, 630.

Sheehan, J. C., and Henery-Logan, K. R. (1957): J. Amer. chem. Soc., 79, 262.

SHEIL, L. P. (1956): Brit. J., vener. Dis., 22, 251.

SOKOlOFF, B. and Goldstein, H. (1963): J. Amer. med. Ass., 184, 197.

Thurman, J. R. (1959): Antibiot. and Chemother, 6, 295.

Willcox, R. R. (1958): Bull. Wld. Hlth. Org., 19, 503.

Willcox, R. R. (1962): Brit. J. clin, Pract., 16, 527.

WiI.LCoX, R. R. (1962a): Brit. J. vener. Dis., 38, 57.

\section{DISCUSSION}

Chairman: D. G. JAmes (London); Participants: C. D. Alergant (Liverpool); B. C. Stratford (Melbourne); R. R. Willcox (London); R. S. Morton (Sheffield); W. M. M. KIRBY (Seattle); G. T. STEWART (Carshalton).

Alergant. When penicillin first became available for treating gonorrhœa-its usefulness was limited by the necessity of requiring multiple injections. The dosage recommended at that time was 40,000 units 3 -hourly for five doses. Lowering the dose or giving fewer injections was always accompanied by a proportion of failures. In other words the gonococcus had to be exposed to a certain minimum concentration of penicillin for a certain minimum time if the infection was to be cured.

The situation was radically altered a few years later by the development of depot preparations and in particular the combination of procaine and penicillin suspended in arachis oil to which was added $2 \%$ aluminium monostearate (P.A.M.). A single injection of 300,000 units of this preparation was found to produce blood levels which were sustained long enough to cure virtually $100 \%$ of cases of gonorrhoea.

At that time nearly all strains of gonococci encountered were inhibited by concentrations in vitro of 0.03 units penicillin/c.c. or less. In the last six or seven years, however, the position has been complicated by the emergence of so called penicillin-resistant gonococci. These strains, which in reality are only relatively penicillin-insensitive, may however 